\title{
Enterprise resource planning implementation in construction: Challenges and key enablers
}

\author{
E. Çınar*, B. Ozorhon \\ Bogazici University, Department of Civil Engineering, Istanbul, Turkey
}

\begin{abstract}
Increased competitiveness forces construction companies to be more productive, efficient, effective, and better integrated. Enterprise resource planning (ERP) tools help construction companies improve their performance levels with the integration of different departments. ERP implementation is critical since the failure rates are high. The major objective of this research is to explore the challenges and key enablers of ERP implementation in construction firms. In this respect, a case study methodology has been employed to three large firms. The findings of the research indicate that reluctance of the employees, lack of scope management, and geographical barriers have been the most significant challenges that the implementation teams encounter. The key enablers to overcome those challenges have been top management support, business process reengineering, clear goals and objectives, competent team and leader, training, and consultancy. This study provides a better understanding of the critical issues of ERP implementation in construction. The findings are expected to guide construction professionals and ERP consultants in the implementation process.
\end{abstract}

\section{Keywords}

Enterprise resource planning; Implementation; Construction industry; Case study

Received: 01 June 2018; Accepted: 27 June 2018

ISSN: 2630-5771 (online) @ 2018 Golden Light Publishing All rights reserved.

\section{Introduction}

Among several information technology (IT) tools, enterprise resource planning (ERP) systems are used by construction companies for higher productivity and effectiveness through improved management of cooperated knowledge and knowhow systems [37]. Tsung [47] defined ERP as "a system that aims to integrate the main business functions across all the departments within an organization”. Negahban [30] indicated that the definition of ERP should be modified for construction as "IT based computer platform that allows for integration of various business processes

\footnotetext{
* Corresponding author

Email: emrahc@boun.edu.tr
}

of an organization in order to increase efficiency, and thus profits, using a single database.”

The root of ERP systems comes from mostly planning systems of production and manufacturing markets [15]. Along with the development of IT technology, Materials Requirement Planning (MRP) systems were improved to ERP systems by adding and enhancing several office tools, such as; sales and CRM modules, human resources, logistics, purchasing and accounting etc. Today, ERP systems support companies combine and cooperate all IT systems of departments into integrated single software based on a single database so that different departments and units of 
a company can more easily reach and share information and communicate with each other.

The construction industry is a highly fragmented industry. Lee et al. [24] stated that by systematizing and computerizing the repeating operations and processes, and decreasing manpower to complete the task, an ERP system can reduce the number of procurement cycles to approximately $80 \%$. Ahmed et al. [3] reported that ERP systems have being used by construction organizations to advance reaction in relation to clients, reinforce supply chain partnerships, improve organizational flexibility, increase decision making proficiencies, and decrease project completion duration and lesser expenses. These ERP systems are developed in order to combine and partly computerize a lot of business processes of construction companies such as; construction site planning, financial management, human resources management, customer relationship management, warehouse management, procurement and tendering.

There are several studies that try to explain the history, functions and characteristics of ERP systems in many different sectors [5, 22, 37, 52]. There is also another other group of studies focusing on the ERP systems developed for or used by construction firms [2, 3, 38, 51]. ERP implementation is very critical since it is not an easy task and there are many failed examples. There are several studies in the literature focusing on the critical success factors (CSF) of EPR implementation in construction [8, 9, 38, 43, 44]. These studies aimed at only identifying the CSFs of adopting ERP systems and used quantitative research methods. An in-depth analysis of the implementation process has not been done considering the challenges faced by the implementation teams and how these problems were overcome through various strategies.

There are a number of studies focusing on ERP implementation in manufacturing and services that deal with single or multiple case studies [29, 33, 35, $45,53,54]$. The success of ERP implementation in construction was investigated by Vlachopoulou and Manthou [49] based on a single firm.
Given this background, the major objective of this paper is to explore (i) the challenges that construction companies encounter during ERP implementation and (ii) the key enablers that help overcome those challenges. In this respect, a case study methodology is employed and the implementation process within three companies is investigated. The findings of this research are expected to guide the construction firms during the ERP implementation process in their organizations.

\section{ERP implementation in construction}

Chen [7] stated that $40 \%$ of all ERP implementations have accomplished only partial implementations and 20\% of ERP implementation efforts are scrapped as total failure. Implementation of a system is a stage that all planned tasks and activities are realized. At the implementation stage, monitoring is essential to make sure that the system is implemented successfully as per the schedule and on the budget. Therefore, the implementation stage begins before project start and continues until the end of the system's test duration.

There are various factors that affect the success of ERP implementation. For example, several authors acknowledged the importance of strong project leaders and champions [4, 13, 28, 32, 42]. Abdinnour-Helm et al. [1] and Lengnick-Hall et.al [25] stated that pre-implementation involvement of end users is a key issue for having a positive attitude towards the ERP systems. Lander et al. [20] considered the trust building mechanism between team members and other participants of the project as a major factor in the implementation process. Somers and Nelson [40, 41] identified top management support, project team competence, clear goals and objectives, vendor support, careful software package selection, user training on software, and use of consultants as critical success factors of ERP implementation. Botta-Genoulaz et al. [6] stated the importance of user training, communication between parties and role of a steering committee. Ferratt et al. [14] mentioned the importance of top management support, user training, team contributions, software selection efforts, information systems area participation and 
consulting capability and support. These factors were also adopted by Chung et al. [8, 9] in their studies that investigated construction ERP success. Similarly, Tatari et al. [43] listed some CSFs in their study such as vendor support, clear goals and objectives, project team competence, careful package selection and user training.

\section{Research methodology}

Questionnaire surveys and case studies are two different methods that could be used in engineering research. Questionnaire surveys focus on the key elements related to research questions but surveys do not provide a full vision and perception into the problem under investigation. However, Yin [36] indicates that case studies aim to answer the 'how' and 'why' questions in a research and allow more in-depth analysis. In this study, it is aimed to employ multiple case study research method and thereby investigate ERP implementation process in construction firms. In this respect, three large scale construction companies are involved in the case studies and these three cases are used to make some comparisons about their implementation strategies and decisions in order to obtain a better understanding of successful implementation of ERP systems.

The validity of the study has been improved by following a number of strategies based on Yin [36]. For example, selection of companies and interviewees is crucial in case study research, thus all interviewees were selected among the team leaders of their ERP implementation projects of large scale and reputable construction companies in Turkey. The total duration of the experiences of the team leaders in construction related industries are between 11 and 15 years, and their ages are between 35 and 45. Interviewee A is the technical office chief of a real estate development company, Interviewee $\mathrm{B}$ is the contract manager of a real estate investment trust and Interviewee $C$ is the planning and cost control expert of a construction company. In order to increase external validity of the study and allow comparisons, multiple case studies are performed. Face-to-face interviews aimed at understanding the ERP implementation process better by mainly focusing on the factors that acted as the challenges and enablers. In addition, the interviews involved questions to learn the reasons why the companies decided to implement ERP; what type of resources were utilized; and to what extent they benefitted from the systems that they implemented. The case study questions and their brief explanations can be found in Table 1.

\subsection{Case study companies}

Company A is a real estate developer and construction company, operating in the sector for 36 years. Their main expertise is multi-purpose high rise buildings. Their domestic turnover is 350 million USD. They use a local ERP system called Yapitasi, which is developed by a Turkish software company for Turkish contractors.

Table 1. Issues discussed during the interviews

\begin{tabular}{|c|c|}
\hline Questions & Explanation \\
\hline $\begin{array}{l}\text { What are the needs that drive the company to implement an ERP } \\
\text { system? (Drivers) }\end{array}$ & $\begin{array}{l}\text { Needs and reasons (organizational, financial, strategic, etc.) that } \\
\text { drive or force the organization to obtain and implement an ERP } \\
\text { systems }\end{array}$ \\
\hline $\begin{array}{l}\text { What are the resources that have been utilized to implement an } \\
\text { ERP system in your company? (Resources) }\end{array}$ & $\begin{array}{l}\text { Resources (financial, technological, or human) that have been } \\
\text { utilized by the implementation team during the implementation of } \\
\text { the system }\end{array}$ \\
\hline $\begin{array}{l}\text { What are the challenges/barriers that are faced by project } \\
\text { implementation team in your company? (Challenges) }\end{array}$ & $\begin{array}{l}\text { Problems or barriers encountered by the key implementation team } \\
\text { members during the implementation period }\end{array}$ \\
\hline $\begin{array}{l}\text { What are the factors facilitating the implementation process of } \\
\text { ERP in your company? (Enablers) }\end{array}$ & $\begin{array}{l}\text { Factors that facilitated the ERP system and helped the } \\
\text { implementation team or consultants }\end{array}$ \\
\hline $\begin{array}{l}\text { What are the achievements through implementation of ERP at } \\
\text { project and corporate level? (Benefits) }\end{array}$ & $\begin{array}{l}\text { Benefits that are achieved through the implementation of the } \\
\text { system at project and wider level }\end{array}$ \\
\hline
\end{tabular}


It took about 1.5 years to implement the system including parallel immigration of the past data of the company. Along with this ERP system, purchasing/procurement, partial accounting, project management with progress payment modules, reporting and planning modules are implemented.

Company B is a real estate investment trust (REIT), operating in the sector for 44 years. They are highly experienced in residential projects. They are traded at the Istanbul Stock Exchange with a public share of $49 \%$ and a market value of 280 million USD. They use an ERP system called Microsoft Dynamics Nav (formerly known as Navison). It took about 3 years to implement the system including parallel immigration of the past data of the company. Along with this ERP system, finance, accounting, project management and planning, purchasing/procurement, human resources (HR), Customer Relationship Management (CRM) and post-sale support systems are implemented.

Company C is a construction company operating in the sector for 17 years. The total value of the projects the company has undertaken amounts to nearly 4.5 billion USD. Its main areas of expertise are industrial facilities, energy projects, urban transformation projects, and housing. They use an ERP system called SAP. It took about 3 years to implement the system. Migration process was not a parallel immigration of the past data but instantaneous migration from old system to new SAP system. Along with this ERP system, finance and financial accounting, cost accounting, material management, purchasing/procurement, project management, maintenance/repair (plant maintenance), human resources, asset management modules are implemented.

Table 2 shows some general information about the companies and the interviewees.

\section{Findings}

\subsection{Drivers}

Based on the findings of three cases, accessing same business data, reporting right and current information about businesses, creating spontaneous management reports are the major reasons why the companies decide to implement ERP systems. Besides these common “drivers", Company A aimed at creating an integrated system that would bring different departments together; Company B planned to use ERP to save time and resources by following business orders easily; and Company C stated that ERP would integrate their different construction sites and headquarters and also ensure connection between different organizations of their group of companies.

\subsection{Resources}

There are various human and financial "resources" that are utilized to implement ERP systems. Among these, allocating funding is the most important input. Extra funds were allocated for training the employees, hiring experienced consultants, and paying for the key implementers. The companies did not indicate the amount of their investment because of confidentiality reasons.

\subsection{Benefits}

"Benefits" have been achieved at both project and corporate level. In terms of project level benefits, creating executive and operational management reports for each construction site fast and easily and accessing the correct and current data from the construction sites at different geographic locations in a faster manner are common project level benefits for all companies. In terms of wider benefits, creating a digital know-how (organizational memory) and providing a vision for the company are the most important benefits for all companies. Besides, ERP systems help the companies increase their feasibility study performances by creating correct and reliable reports for short and long term. Moreover along with the new ERP systems, some processes are revised and enhanced due to business process reengineering (BPR). The importance of $B P R$ is mentioned in later sections. 
Table 2. Key information on the case studies

\begin{tabular}{|c|c|c|c|}
\hline Case & A & B & $\mathrm{C}$ \\
\hline Company age (years) & 37 & 45 & 18 \\
\hline Type of the company & Real estate developer & Real estate investment trust & Contractor \\
\hline Experience of the interviewee (years) & 15 & 11 & 13 \\
\hline Business title of the interviewee & Technical Office Chief & Contract Manager & Planning and Cost Control Expert \\
\hline ERP system in use & Yapitasi & MS Navison (MS Dynamics) & SAP \\
\hline Implementation duration (years) & 1.5 & 3 & 3 \\
\hline Modules of the ERP system & $\begin{array}{ll} & \\
\text { - } & \text { Purchasing/ } \\
\text { Procurement } \\
\text { - } & \text { Accounting } \\
\text { (Partially) } \\
\text { - Project } \\
\text { Management } \\
\text { with } \\
\text { progress } \\
\text { payment } \\
\text { Planning }\end{array}$ & $\begin{array}{ll}\text { - } & \text { Finance } \\
\text { - } & \text { Accounting } \\
\text { Project } \\
\text { management and } \\
\text { planning } \\
\text { - } & \text { Purchasing/ } \\
\text { Procurement } \\
\text { - } \\
\text { Human resources } \\
\text { management } \\
\text { (HRM) } \\
\text { Customer } \\
\text { relationship } \\
\text { management } \\
\text { (CRM) } \\
\text { Post-sale support } \\
\text { systems }\end{array}$ & $\begin{array}{ll}\text { - } & \text { Financial accounting } \\
\text { - } & \text { Cost accounting } \\
\text { - } & \text { Material management } \\
\text { - } & \text { Prochasing/ } \\
\text { - } & \text { Project management } \\
\text { - } & \text { Humant maintanance } \\
\text { - } & \text { management (HRM) } \\
& \text { Asset management }\end{array}$ \\
\hline
\end{tabular}

\subsection{Challenges}

The "challenges" encountered by the project implementation teams can be grouped under three categories, including reluctance of employees, lack of scope management, and geographical barriers.

(i) Reluctance of employees: The companies struggle to implement ERP systems because they are resistant to change; they face adaptation problems since they lack necessary knowledge. Employees are assigned an extra amount of work due to a new system being introduced in the companies. Apart from daily responsibilities, dealing with a new task takes time and effort that might create a negative impact on most employees. This in turn can cause some resistance to accept the new system as well. The interviewees indicated that the most significant challenges have been the old habits of the employees; resistance to leave the old system and procedures; and impatience to the errors and mistakes at the implementation phase. Similar challenges are mentioned in Robey et al.'s [33] study as well. (ii) Lack of scope management: Interviewees mentioned that the companies lack an ERP strategy at the implementation phase. This creates some crucial negative impacts during the implementation phase. Clear definition of goals and objectives by top management about what is expected from ERP systems are very critical. Many researchers indicated the significance of defining clear goals and objectives by an effective scope management of top management level of the organizations [9, 18, 21, 30, 39, 40, 41, 43, 44, 46, 48].

(iii) Geographical barriers: Most construction firms operate in different locations. Having multiple construction sites at different regions of the world, experiencing internet connection problems, not being able to train employees at each site are among the geographical barriers that the implementation teams encounter. This is an important finding of the study, since previous works have not mentioned such a challenge for ERP implementation. This kind of geographical barriers can be solved by using satellite connections but the cost of this kind of internet infrastructure investments to the project sites can be very high 
with respect to other kind of local internet connection tools.

\subsection{Enablers}

There are various factors that helped overcome the challenges and facilitated the implementation of ERP systems in the companies. These can be grouped under six categories namely top management support; BPR; clear goals and objectives; implementation team and leader; training; and consultancy.

(i) Top management support: In terms of the enablers facilitating implementation process of ERP systems, the most significant one for all three cases has been top management support. The motivation of the key implementation team is crucial and this motivation can be ensured mostly by top management level executives by demonstrating the outcomes and benefits of ERP implementation to their organizations. The importance of top management support and commitment is also mentioned in many other studies [6, 9, 14, 40, 41, 43, 44, 48].

(ii) Business process reengineering (BPR): BPR has been another critical factor for ERP implementation success. BPR is related to organizational change management and revision of business work flows. Various studies emphasized the importance of organizational change management [3, 6, 8, 10, 11, 19, 31, 40, 41, 44]. Interviewee $\mathrm{B}$ and $\mathrm{C}$ have approved that they have had BPR operations during the implementation and some procedures in the organization have changed according to new ERP system. It should be noted that BPR requires top management support, which was the case for Companies B and C.

(iii) Clear goals and objectives: All three companies indicated that top management should be clear about what to expect from the ERP implementation. Having an ERP strategy and thereby setting clear goals and objectives is very critical as also highlighted in literature [9, 18, 21, 30, 39, 40, 41, 43, 44, 46, 48]. Similarly, planning the system and choosing the modules correctly is very crucial. Choice of ERP software package [9, $14,43]$ and choice of ERP modules [9, 14, 40, 41] have been also indicated as a critical success factor of ERP implementation.

(iv) Implementation team and leader: Right and competent key implementation team and team members has been mentioned by the interviewees as a key enabler. This corresponds to project team competence as mentioned in many relevant studies, i.e., Davis and Wilder [12], Minahan [27], Laughlin [23], Robey et al. [33], Somer and Nelson [40, 41], Umble et al. [48], Lander et al. [20] and Tatari et al. [43]. Besides having a competent team, an effective and experienced implementation team leader is necessary to plan the process and motivate the team. Effectiveness of project leader as a CSF has also been mentioned in Beath [4], Morris [28], Roure [34], Sumner [42], Parr et al. [32], Esteves and Pastor [13], and Somer and Nelson [40, 41]. If the members of the implementation team are not competent enough and their leader is weak, then one would expect problems during the process.

(v) Training: Training end users is among the key enablers that the interviewees highlighted. Hutchins [17], Laughlin [23], McCaskey [26], Volwer [50], Somer and Nelson [40, 41], Botta-Genoulaz et al. [6], Ferratt et al. [14], Tatari et al. [43], Negahban [30], Tatari and Skibniewski [43] have also stated that training and support for users is a significant factor contributing to ERP success. Regular training was effective to overcome the reluctance of the employees and remove knowledge barriers.

(vi) Consultancy: Choosing a right consultant has been among the key enablers of ERP implementation. The importance of consultancy and vendor support has also been highlighted in previous work including Somer and Nelson [40, 41], Gargeya and Brady [16], Ferratt et al. [14], Chung et al. [9], Tatari et al. [2008], Tatari and Skibniewski [44]. Asking own employees to help external consultants is an important factor in order to use of the consultants effectively. End user involvement is critical since the end users provide important information for the external consultants about the old procedures and general information about the organization and data flow. 


\subsection{Overall evaluation of the cases}

ERP implementation has been considered successful by Company $\mathrm{B}$ and $\mathrm{C}$, whereas the interviewee from Company A has defined the process as failure. The major reasons why the implementation process has been indicated as a failure are numerous. The interviewee stated that in the long run, end users and other significant employees in Company A have shown a strong resistance to the new system. There was an adaptation problem between people and the system. In addition, top management level did not support the system enough; they were not committed in the long run. As a result of these problems, most of the modules of the ERP system were not used and the businesses were continued to perform in an old fashion manner. The system in Company A can be referred to a prematurely-implemented ERP system.

As one of the successful implementations, the process in Company B was achieved through top management support, right and competent key implementation team members, right and competent consultants, setting clear goals and objectives, training employees continuously and having support from the ERP vendor. In case of Company C, the major factors can be listed as top management support, right and competent key implementation team members, right and competent consultants, BPR, having support from ERP vendor, allocating extra fund to in order to train end users, proper planning of the system at the beginning of the implementation phase, hiring full time key implementation team that focused only on the ERP system, using this team as interior consultant after implementation system is done, preferring direct immigration instantly rather than parallel immigration, providing a back-up system, and training employees.

The most important lesson learnt based on these three cases is that the human aspect is the most critical component of implementation success. The focus should be on the key implementation team members, end users and consultants not only on the technology component. As one of the interviewees stated "not the computers we have used but the implementation team members are carrying out all the implementation procedures. Therefore, even if the aim of the whole process is developing a very detailed and advanced computer system, the main attention should be paid to the humans; the end users of the company, the members of the implementation team and the consultants. A successful implementation of any system could be achieved only if these people have become the focus of the whole process."

Table 3 summarizes the challenges and the enablers in each case study.

\section{Discussion}

In construction sector, competition has been increasing continuously and market conditions have been forcing companies to manage their project more efficiently and effectively. At this point, ERP systems present an integrated IT solution for the projects of construction organizations and assist the companies to work more effectively. There are studies that focused on the business benefits of ERP in construction. In order to fully benefit from what ERP offers, the previous examples and business cases should be investigated. The major objective of this study was to investigate the ERP implementation process in construction firms and its characteristic features by identifying drivers, resources, challenges, enablers, and benefits.

Table 3. A summary of case study findings

\begin{tabular}{|c|c|c|c|c|}
\hline & \multirow{2}{*}{ Factors } & \multicolumn{3}{|c|}{ Company } \\
\hline & & A & $\mathrm{B}$ & C \\
\hline \multirow{3}{*}{ CHALLENGES } & Reluctance of employees & $\sqrt{ }$ & $\sqrt{ }$ & $\sqrt{ }$ \\
\hline & Lack of scope management & $\sqrt{ }$ & $\sqrt{ }$ & - \\
\hline & Geographical barriers & - & - & $\sqrt{ }$ \\
\hline \multirow{6}{*}{ ENABLERS } & Top management support & $\sqrt{ }$ & $\sqrt{ }$ & $\sqrt{ }$ \\
\hline & $\begin{array}{l}\text { Business process } \\
\text { reengineering }\end{array}$ & - & $\sqrt{ }$ & $\sqrt{ }$ \\
\hline & Clear goals and objectives & - & $\sqrt{ }$ & $\sqrt{ }$ \\
\hline & $\begin{array}{l}\text { Implementation team and } \\
\text { leader }\end{array}$ & - & $\sqrt{ }$ & $\sqrt{ }$ \\
\hline & Training & $\sqrt{ }$ & $\sqrt{ }$ & $\sqrt{ }$ \\
\hline & Consultancy & - & $\sqrt{ }$ & $\sqrt{ }$ \\
\hline
\end{tabular}


In this respect, three case studies are performed with the key implementers of ERP systems in large scale and reputable construction companies of Turkey.

The findings suggest that there are some common challenges that key implementation team members are exposed to. Those are grouped under 3 subtitles as follows; reluctance of employees, lack of scope management, and geographical barriers. Reluctance of the employees can be very damaging and lack of change management during the implementation could cause failure of the project if the relation between the employees and the new system is not properly performed. If a company has branches or construction sites at different regions of the world, some geographical barriers can be seen during the implementation of ERP systems. Although this is not reported to as a challenge in previous studies, it is highly probable that an international contractor will face such a barrier, therefore companies doing business abroad should plan their ERP implementation even more carefully. The findings also suggest that there are some common enablers that key implementation team members have benefitted from. Those are grouped under 6 subtitles as follows; top management support, BPR, clear goals and objectives, implementation team and leader, training, and consultancy. Top management support was key and crucial enablers for all three implementation team members because of the fact that along with ERP system, the organizations will be exposed to changes at information flow, so the reaction and the resistance from the employees of the company can be eliminated through top management support and commitment. Lack of scope management can also be eliminated through setting clear goals and objectives. In order to do that, top management level executives should know what they are expecting from the system. Competent key implementation team and an effective team leader is a must for a problem-free ERP implementation period. Training the employees regularly is very crucial to ensure that the new system is accepted by all members in the organization. Competent consultants and right use of consultants are also essential to eliminate possible problems. Support from ERP vendor should be sustained throughout the implementation process.

\section{Conclusions}

One of the contributions of this study is that it identifies the drivers, resources, and benefits of ERP systems but mainly focuses on the challenges faced by key implementation teams during ERP implementations and the enablers through which those challenges are removed. The findings of this study can be helpful to guide the senior managers of construction companies and ERP consultants to effectively implement ERP in the construction sector. This research is based on the data collected from three case studies from Turkey; therefore, it reflects the experiences of those firms. However, similar studies can be performed to observe marketspecific differences in terms of ERP implementation success.

\section{References}

[1] Abdinnour-Helm, S., Lengnick-Hall M. L., Lengnick-Hall, C. A. Preimplementation attitudes and organizational readiness for implementing an enterprise resource planning system. European Journal of Operational Research 146(2) (2003) 258-273.

[2] Adam, F., O'Doherty, P. Lessons from enterprise resource planning implementations in Ireland towards smaller and shorter ERP projects. Journal of Information Technology 15 (2000) 305-316.

[3] Ahmed, S. M., Ahmad, I., Azhar S., Mallikarjuna S. Implementation of enterprise resource planning (ERP) systems in the construction industry. Proceedings of the ASCE Construction Research Congress, 19-21 March 2003, Honolulu, Hawaii.

[4] Beath, C. Supporting the information technology champion. MIS Quarterly 15(3) (1991) 355-371.

[5] Bell, L. C., Stukhart G. Cost and benefits of material management systems. Journal of Construction Engineering Management 113(2) (1987) 222-234.

[6] Botta-Genoulaz, V., Millet P. A., Grabot B. A survey on the recent research literature on erp systems. Journal of Computers in Industry 56 (2005) 510-522. 
[7] Chen, I. C. Planning for ERP systems: analysis and future trend business. Process Management Journal 7(5) (2001) 374-386.

[8] Chung, B., Skibniewski, M. J., Kwak, Y. H. Developing ERP systems success model for the construction industry. Journal of Construction Engineering and Management 135(3) (2009) 207216.

[9] Chung, B., Skibniewski, M. J., Lucas, Jr. H. C., Kwak, Y. H. Analyzing enterprise resource planning (ERP) systems implementation success factors in the engineering-construction industry. Journal of Computing in Civil Engineering 22(6) (2008) 373-382.

[10] Daneva, M. ERP requirements engineering practice: lessons learned. Software 21(2) (2004) 26-33.

[11] Daneva, M. Lessons learnt from five years of experience in ERP requirements engineering. Proceedings of the 11th IEEE International Requirements Engineering Conference, 12-12 September 2003, Monterey Bay, CA, USA..

[12] Davis, B., Wilder, C. False starts, strong finishescompanies are saving troubled IT projects by admitting their mistakes, stepping back, scaling back, and moving on. Information Week, 30 November 1998, pp 41-43.

[13] Esteves, J., Pastor, J. Analysis of critical success factors relevance along SAP implementation phases. Americas Conference on Information Systems, 2001, Boston, USA.

[14] Ferratt, T. W., Ahire, S., De, P. Achieving success in large projects: implications from a study of ERP implementations. Interfaces 36(5) (2006) 458-469.

[15] Fitzgerald, A. Enterprise Resource Planning. IEE Conference Publication 359. Institute of Electrical Engineers, London, 1992, pp 291-297.

[16] Gargeya, V. B., Brady, C. Success and failure factors of adopting SAP in ERP system implementation. Business Process Management Journal 11(5) (2005) 501-516.

[17] Hutchins, H. 7 key elements of a successful implementation, and 8 mistakes you will make anyway. APICS International Conference Proceedings, 1998, Falls Church, VA.

[18] Krupp, J. Transition to ERP implementation. APICS - The Performance Advantage, October 1998, pp 4-7.

[19] Kyung-Kwon, H., Young-Gul, K. The critical success factors for ERP implementation: an organizational fit perspective. Information and Management 40(1) (2002) 25-40.

[20] Lander, M. C., Purvis R. L., McCray G. E., Leigh W. Trust building mechanisms utilized in outsourced IS development projects: a case Study. Information and Management 41(4) (2004) 509528.

[21] Latamore, G. Flexibility fuels the ERP evolution. APICS-The Performance Advantage, October, 1999, pp. 44-50.

[22] Laudon, K.C., Laudon J. P. Management Information Systems: Managing the Digital Firm, 2nd edition, Prentice Hall Inc., Upper Saddle River, NJ, 2002.

[23] Laughlin, S. An ERP game plan. Journal of Business Strategy January - February (1999) 3237.

[24] Lee, S., Arif, A., Halpin, D. Simulation modeling by enterprise resource planning implementation in medium sized corporation. Proceedings of First International Conference on Construction in the 21st Century (CITC-2002), 2002, Miami, Florida.

[25] Lengnick-Hall, C., Lengnick-Hall, M., AbdonnourHelm, S. The role of social and intellectual capital in achieving competitive advantage through enterprise resource planning (ERP) systems. Journal of Engineering and Technology Management 21(4) (2004) 307-330.

[26] McCaskey, D., Okrent, M. Catching the ERP second wave. APICS - The Performance Advantage, December 1999, pp 34-38.

[27] Minahan, T. Enterprise resource planning. Purchasing 16 (1998) 112-117.

[28] Morris, P. Project management: Lessons from IT and Non-IT Projects. In: Earl MJ. (ed) Information Management: The Organizational Dimension, Oxford University Press, 1996, pp 321-336.

[29] Motwani, J., Mirchandani, D., Madan, M., Gunasekaran, A. Successful implementation of ERP projects: evidence from two case studies. International Journal of Production Economics 75(1/2) (2002) 83-96.

[30] Negahban S. Utiliation of enterprise resource planning tools by small to medium size construction organizations: a decision-making model. PhD Thesis, University of Maryland, 2008.

[31] Oliver, D., Romm, C. Justifying enterprise resource planning adoption. Journal of Information Technology 17(4) (2002) 199-213.

[32] Parr A., Shanks G., Dark P. Identification of necessary factors for successful implementation of 
ERP systems. In: Ngwenyama O, Introna LD, Myers M, DeGross J. (ed) New information technologies in organizational processes, field studies and theoretical reflections on the future work, Kluwer academic publishers, 1999, pp 99119.

[33] Robey, D., Ross, J., Boudreau, M. Learning to implement enterprise systems: an exploratory study of the dialectics of change. Journal of Management Information Systems 19 (1) (2002) 17.

[34] Roure, L. Cultural differences in product champions characteristics: a comparison of France and Germany. Centre de Recherche DMSP, cahier no 268, 1999, Mars.

[35] Sarkis, J. Sundarraj, R. P. Managing large-scale global enterprise resource planning systems: a case study at Texas Instruments. International Journal of Information Management 23(5) (2003) 431-442.

[36] Yin, R. K. Case Study Research: Design and Methods. 4th edition. Sage Publications, Thousand Oaks, CA, 2009.

[37] Shi, J. J., Halpin, D. W. Enterprise resource planning for construction business management”, Journal of Construction Engineering and Management 129(2) (2003) 214-221.

[38] Skibniewski, M. J., Ghosh, S. Determination of key performance indicators with enterprise resource planning systems in engineering construction firms. Journal of Construction Engineering and Management 135(10) (2009) 965-978.

[39] Schragenheim, E. When TQM and ERP worlds collide. APCIS, February, 2000, 55(7).

[40] Somers, T. M., Nelson, K. The impact of critical success factors across the stages of enterprise resource planning implementations. IEEE Proceedings of the 34th Hawaii International Conference on System Science, January 2001, Washington, DC, USA.

[41] Somers, T. M., Nelson, K. G. A Taxonomy of players and activities across the ERP project life cycle. Information and Management 41(3) (2004) 257-278.

[42] Sumner, M. Critical success factors in enterprise wide information management systems projects. Americas Conference on Information Systems, 1999, Milwaukee. Wisconsin, USA.

[43] Tatari, O., Castro-Lacouture, D., Skibniewski, M. J. Performance Evaluation of Construction Enterprise Resource Planning Systems. Journal of Management in Engineering 24(4) (2008) 198206.
[44] Tatari, O., Skibniewski, M. J. Empirical analysis of construction enterprise information systems: assessing system integration, critical factors, and benefits. Journal of Computing in Civil Engineering 25(5) (2011) 347-356.

[45] Tatsiopoulos, I., Panayiotou, N., Kirytopoulos, K., Tsitsiriggos, K. Risk Management as A Strategic Issue for the Implementation of ERP Systems: A Case Study from the Oil Industry. In: Dorhgam MA. (ed) International Journal of Risk Assessment and Management, Inderscience Publishers, 4(1), 2003, pp 20-35.

[46] Travis, D. Selecting ERP. APICS - The Performance Advantage, June 1999, pp 37-39.

[47] Tsung, S. M. M. ERP - A Route Toward Successful Implementation. University of Leeds, School of Computing, Leeds, 2004.

[48] Umble, E., Haft, R., Umble, M. Enterprise resource planning: implementation procedures and critical success factors. European Journal of Operational Research 146(2) (2003) 241-257.

[49] Vlachopoulou, M. and Manthou, V. Enterprise resource planning (ERP) in a construction company. International Journal of Business Information Systems 1(3) (2006) 339-351.

[50] Volwer, J. Learning in the play pit. Computer Weekly 27(34) (1999).

[51] Voordijk, H., Van Leuven, A., Laan, A. Enterprise resource planning in a large construction firm: implementation analysis. Construction Management and Economics 21 (2003) 511-521.

[52] Willcocks, L. P., Sykes, R. The role of the CIO and IT function in ERP. Communications of the ACM 43(4) (2000) 32-38.

[53] Yusuf, Y., Gunasekaran, A., Abthorpe, M. S. Enterprise information systems project implementation: a case study of ERP in RollsRoyce. International Journal of Production Economics 87(3) (2004) 251-266.

[54] Yen, H. R., Sheu, C. Aligning ERP implementation with competitive priorities of manufacturing firms: an exploratory study. International Journal of Production Economics 92(3) (2004) 207-220. 